Stimulation of Short-term Plant

\title{
Growth by Glycerol Applied as Foliar Sprays and Drenches under Greenhouse Conditions
}

\author{
Brent Tisserat $^{1}$ and Amy Stuff \\ Functional Foods Research Unit, USDA/ARS, National Center for Agricultural \\ Utilization Research, 1815 N. University Street, Peoria, IL 61604
}

Additional index words. spearmint, carrot, color alterations, roots, corn, growth stimulation, plant pigments

\begin{abstract}
The effects of aqueous solutions applied as foliar spray and drench applications of glycerol were tested on the 'Chantenay' carrot (Daucus carota L.) family Apiaceae, corn (Zea mays L.) family Poaceae, and spearmint (Mentha spicata L.) family Lamiaceae under greenhouse conditions. Foliar sprays and drenches were administered to carrots at concentrations of $0,1,3,5,10,25$, or $50 \mathrm{ml} \cdot \mathrm{L}^{-1}$. Fresh weights, dry weights, and taproot diameter from carrot seedlings sprayed with a solution containing $5 \mathrm{~mL} \cdot \mathrm{L}^{-1}(50 \mathrm{~mm})$ glycerol increased $105.6 \%, 158.4 \%$, and $53.8 \%$, respectively, when compared with untreated carrots. Foliar sprays were administered to corn at concentrations of $0,0.1$, $0.3,0.5$, and $1 \mathrm{ml} \cdot \mathrm{L}^{-1}$ and spearmint at concentrations of $0,1,5$, and $10 \mathrm{~mL} \cdot \mathrm{L}^{-1}$. Growth responses increased in corn and spearmint by using certain glycerol concentrations. Fresh weights, dry weights, and shoot length from corn seedlings sprayed with a solution containing $0.5 \mathrm{~mL} \cdot \mathrm{L}^{-1}(5 \mathrm{~mm})$ glycerol increased $83.5 \%, 154.6 \%$, and $90.9 \%$, respectively, when compared with untreated corn. Fresh weights, dry weights, and shoot length from mint plants sprayed with a solution containing $5 \mathrm{~mL} \cdot \mathrm{L}^{-1}(50 \mathrm{~mm})$ glycerol increased $46.6 \%, 68.7 \%$, and $102.5 \%$, respectively, when compared with untreated plants. Glycerol applications can stimulate growth responses in diverse plant species.
\end{abstract}

The U.S. Federal mandates affecting biodiesel production include the Energy Policy Act, which requires specific levels of alternative fuel use in federal automobile fleets, and the Clean Air Act, which requires all diesel fuel sold for on-road use to be ultralow in sulfur emissions by 2006 (Demirbas, 2009; Ebert, 2007; McIntyre, 2007). This legislation has resulted in a number of governmental biodiesel incentive programs, which contributed toward a U.S. biodiesel market of 150 million gallons production per year in 2006 (double the 75 million gallons per year produced in 2005) and have an anticipated future of 2 billion gallons per year production expected by the year 2015 (Ebert, 2007; McIntyre, 2007). The U.S. biodiesel industry vegetable feedstocks current output is 3.8 billion gallons of fats and oils annually. For every 10 gallons of biodiesel produced, 1 gallon of glycerol is generated through transesterification of animal and vegetable oils (Demirbas, 2009; Kenar, 2007). This

Received for publication 14 June 2011. Accepted for publication 15 Sept. 2011.

We thank Debra Palmquist for statistical analysis. Mention of trade names or commercial products in this article is solely for the purpose of providing scientific information and does not imply recommendation or endorsement by the U.S. Department of Agriculture. USDA is an equal opportunity provider and employer.

${ }^{1}$ To whom reprint requests should be addressed; e-mail brent.tisserat@ars.usda.gov. dramatic biodiesel production increase over the past 5 years has resulted in decreasing glycerol prices resulting from excessive production. Commercialization of the glycerol generated by this industry is therefore becoming increasingly important (Ebert, 2007; Lines, 2009; McIntyre, 2007; Pachauri and He, 2006). Developing higher-valued products from glycerol would improve investment returns to the biodiesel industry. The historic markets for glycerol (e.g., antifreeze agents, food additives, cosmetics, and health products) are already limited; therefore, new products are needed (Ebert, 2007; Lines, 2009). Glycerol is a nontoxic, edible, biodegradable sugar alcohol making it an ideal "environmentally friendly" agricultural chemical. The influence of glycerol on plant tissue cells has been repeatedly demonstrated in its use as a cryoprotective agent used in cell and tissue cyrogenetic storage (Kim and Oh, 2009; Panis and Lambardi, 2005; Silayoi, 2001; Towill and Mazur, 1976; Withers and King, 1979).

Glycerol has also been used in tissue culture studies using numerous plants - seaweed [Grateloupia filicina (J.V. Lamouroux) C. Agardh], kelp (Ecklonia radiata J. Agardh), morning glory (Pharbitis nil L.), Orchid tree (Bauhinia forticata Link), zedoary (Curcuma zedoaria Roscoe), bean (Phaseolus vulgaris L.), sweet orange [Citrus sinensis (L.) Osbeck] (Baweja and Sahoo, 2009; Hisajima and Thorpe, 1985; Lawlor et al., 1989; Mello et al., 2001; Vu et al., 1993). Glycerol has also been used as a carbohydrate supplement to stimulate algae tissue culture growth (Baweja and Sahoo, 2009; Kaczyna and Megnet, 1993; Lawlor et al., 1989; Marián et al., 2000; Robaina et al., 1990). For example, red algae [Gracilaria verrucosa (Hudson) Papenfuss] grown on $217 \mathrm{~mm}$ (i.e., $20 \mathrm{~mL} \cdot \mathrm{L}^{-1}$ ) glycerol with plant growth regulators $\left(2 \mathrm{mg} \cdot \mathrm{L}^{-1}\right.$ indole-3propionic acid, $2 \mathrm{mg} \cdot \mathrm{L}^{-1}$ indole-3-acetic acid, $1 \mathrm{mg} \cdot \mathrm{L}^{-1} \mathrm{~N}$-isopentenyladenine) stimulated callus growth (Kaczyna and Megnet, 1993).

Glycerol has been used in higher plant tissue cultures with mixed results (Aubert et al., 1994; Bellettre et al., 2001; Gautheret, 1955). Generally, glycerol is a poor substitute for sucrose or the reducing sugars (glucose or fructose) as a carbon source of plant cell cultures (Gautheret, 1955; Hisajima and Thorpe, 1985; Mello et al., 2001; Vu et al., 1993; Vuke and Mott, 1987). Aubert et al. (1994) studied the influence of glycerol on cell metabolism of sycamore (Acer pseudoplatanus L., family Sapindaceae) whereby callus was removed from sucrose and grown solely on glycerol for short durations. Chicory hybrid '474' (Cichorium intybus $\mathrm{L}$. var. sativum $\times C$. endivia $\mathrm{L}$. var. latifolia, family Asteraceae) leaf tissues cultured on a combination of sucrose and glycerol manifested somatic embryogenesis (Bellettre et al., 1999, 2001). Several citrus tissue culture investigators have reported stimulation of somatic embryogenesis using glycerol (Ben-Hayyim and Goffer, 1989; Ben-Hayyim and Neumann, 1983; Singh et al., 1992; Tomaz et al., 2001; Vu et al., 1993). For example, $\mathrm{Vu}$ et al. (1993) reported that 'Hamlin' sweet orange nucellar callus grown on medium substituting $2 \%$ glycerol for $5 \%$ sucrose promoted more somatic embryogenesis, chlorophyll formation, and $\mathrm{RuBisCO}$ activity.

According to a report issued by the Glycerin Producers' Association (1964), glycerol has several potential uses in the agricultural, floricultural, and horticultural fields (Anonymous, 2011). Glycerol ( 0.1 to $10 \%)$ can be substituted for water to moisten peatmoss around roots before shipping resulting in more successful transplanting. Narcissus sp. bulbs grown in gravel with diluted glycerol solutions exhibited greater growth and flowering (Anonymous, 2011). Glycerol has also been used to prevent freezing of branches, leaves, buds, and blossoms if used as a spray consisting of water, glycerol, a spreader, and alcohol (Anonymous, 2011). In this case, the protective coating that formed on the plant surfaces insulated plant tissues from the freezing temperatures.

Soaking seeds in glycerol can counteract the adverse effect of salinity on growth and secondary metabolism (Ali et al., 2008). Seeds of Castor bean (Ricinus communis L.) soaked for $48 \mathrm{~h}$ in 5,25 , or $50 \mathrm{~mm}$ glycerol or a mixture of 10:5, 25:10, and 50:15 mm glycerol:aspartic acid, respectively, resulted in seedlings exhibiting higher fresh and dry weights than seedlings obtained from watersoaked seeds. In addition, essential oil and alkaloid contents were higher in plants derived from glycerol treated seeds than controls in saline environments (Ali et al., 2008).

Despite these positive reports, glycerol is not commercially used to promote plant growth 
for agricultural or horticultural systems. The purpose of these studies was to conduct shortterm experiments with various plants to evaluate the merits of using glycerol as drenches or foliar sprays within the relatively uniform environment of a greenhouse.

\section{Materials and Methods}

Plant materials. Carrot seeds (Daucus carota L. 'Chantenay'), Dwarf Corn (Zea mays L. cv. Gaspé Flint) seeds, and spearmint (Mentha spicata L. PI \# '294099') plantlets as sterile shoot cuttings were used. 'Chantenay' carrot was selected for its rapid root formation, dwarf corn because it could accommodate the limited greenhouse space, and cloned spearmint plantlets to ensure a uniform response.

Greenhouse experiments. All plants were grown on a soilless medium formulated with 1 Canadian sphagnum peatmoss (Ferti-lome, Cheek Garden Products, Austin, TX):1 coarsegrade vermiculite (Premium Grade; Sun-Gro Horticulture Dist. Inc., Bellevue, WA), and amended with $10.9 \mathrm{~g} \cdot \mathrm{kg}^{-1}$ Micromax (Scotts Co., Marysville, $\mathrm{OH}$ ) of $14 \mathrm{~S}-15 \mathrm{Fe}-2.5 \mathrm{Mn}-$ $1.5 \mathrm{Mg}-1 \mathrm{Cu}-1 \mathrm{Zn}-0.2 \mathrm{~B}-0.05 \mathrm{Mo}$, and 62.2 $\mathrm{g} \cdot \mathrm{kg}^{-1}$ Osmocote (Scotts Co.) of $14 \mathrm{~N}-4.2 \mathrm{P}$ $11.6 \mathrm{~K}$. Carrots were grown in containers $(3.8 \mathrm{~cm}$ diameter $\times 21 \mathrm{~cm}$ high) containing $50 \mathrm{~g}$ medium. Spearmint and corn were grown in $4 \frac{1}{2}$ " rectangular pots $(10.8 \mathrm{~cm}$ wide $\times 9.5 \mathrm{~cm}$ high $\times 11.4 \mathrm{~cm}$ deep) containing $100 \mathrm{~g}$ medium. Aqueous glycerol solutions were prepared with distilled water and food-grade glycerol (99.7\%) (Soap Goods, Atlanta, GA). To determine the effect of glycerol on carrot growth and morphogenesis, 202 -week-old seedlings were treated with foliar sprays at concentrations (Table 1). Foliar sprays were administered with handheld trigger spray bottles (24 oz. cap.) (U.S. Plastic Corp., Lima, OH) until liquid began to drain off the leaves $(\approx 2.5$ $\mathrm{mL} /$ plant). The same concentrations were also administered to seedlings as a soil drench using aliquots of $25 \mathrm{~mL} /$ container (Table 1). Glycerol treatments were given to carrot plants twice, first at the initiation of the experiment and a second time 4 weeks later (Table 1). Experiments were ended 8 weeks past application of the first glycerol treatment. Two-week-old corn seedlings were sprayed with $25-\mathrm{mL}$ aliquots of glycerol twice, first at the initiation of the experiment and 2 weeks later (Table 1). Experiments were ended at the end of 4 weeks from the time of the first foliar application. Spearmint plants were maintained on agar Murashige and Skoog medium containing 3\% sucrose in vitro as shoot cuttings. Eight-weekold plantlets were removed from agar medium, rinsed with water to remove excess agar and sucrose, and then established in $4 \frac{1}{2} 2^{\prime \prime}$ pots and kept under high humidity conditions for 2 weeks to become acclimated to greenhouse conditions. Soil-established plantlets were then sprayed once with $25-\mathrm{mL}$ aliquots of glycerol (Table 1). Experiments were ended at the end of 4 weeks from the time of the first foliar application. Plants were watered four times per week. Experiments were repeated in the greenhouse at least twice using 20 replications per treatment between 2008 and 2010. Average daily temperature was $25{ }^{\circ} \mathrm{C}$ and varied from 20 to $29^{\circ} \mathrm{C}$. Illumination during experiments was provided by natural and artificial lighting as necessary with an average daily photosynthetic photon flux of 630 to $700 \mu \mathrm{mol} \cdot \mathrm{m}^{-2} \cdot \mathrm{s}^{-1}$.

Statistical analysis. Ten seedlings for each treatment were analyzed for shoot and root

fresh weights and dry weights, tap root diameters (carrot only), and shoot and root lengths. Best fit regression equations were calculated with Table Curve 2D software Version 5.0 (Systat Software, Inc., San Jose, CA) for each response variable as a function of glycerol concentration. Regression model analyses and 95\% confidence limits on the mean predicted

Table 1. Glycerol treatments and concentrations applied to plants.

\begin{tabular}{llc}
\hline Plant & Treatment & \multicolumn{1}{c}{ Glycerol concn $\left[\mathrm{mL} \cdot \mathrm{L}^{-1}(\mathrm{mM})\right]$} \\
\hline Carrot & Spray & $0(0), 1(11), 3(33), 5(50), 10(109), 25(271), 50(543)$ \\
Carrot & Drench & $0(0), 1(11), 3(33), 5(50), 10(109), 25(271), 50(543)$ \\
Corn & Spray & $0(0), 0.1(1.1), 0.3(3.3), 0.5(5), 1(11)$ \\
Spearmint & Spray & $0(0), 1(11), 5(50), 10(109)$ \\
\hline
\end{tabular}

Table 2. Influence of aqueous glycerol spray concentrations on carrot taproot color parameters from internal carrot cut $1 \mathrm{~cm}$ below shoot. ${ }^{\mathrm{z}}$

\begin{tabular}{lccccc}
\hline & \multicolumn{5}{c}{ Color parameters $^{\mathrm{y}}$} \\
\cline { 2 - 6 } Glycerol concn $\left(\mathrm{mL} \cdot \mathrm{L}^{-1}\right)$ & $\mathrm{L}^{*}$ & $\mathrm{a}^{*}$ & $\mathrm{~b}^{*}$ & $\mathrm{C}^{*}$ & $\mathrm{H}^{*}$ \\
\hline 0 & $32.81 \mathrm{a}$ & $14.07 \mathrm{a}$ & $18.84 \mathrm{a}$ & $23.48 \mathrm{a}$ & $0.896 \mathrm{a}$ \\
1 & $32.82 \mathrm{ab}$ & $17.37 \mathrm{~b}$ & $20.69 \mathrm{ab}$ & $37.20 \mathrm{ab}$ & $0.895 \mathrm{a}$ \\
3 & $33.01 \mathrm{ab}$ & $17.92 \mathrm{~b}$ & $21.79 \mathrm{~b}$ & $28.27 \mathrm{~b}$ & $0.892 \mathrm{a}$ \\
5 & $35.83 \mathrm{~b}$ & $18.17 \mathrm{~b}$ & $22.08 \mathrm{~b}$ & $28.55 \mathrm{~b}$ & $0.890 \mathrm{a}$ \\
10 & $34.49 \mathrm{ab}$ & $18.51 \mathrm{~b}$ & $22.25 \mathrm{~b}$ & $28.78 \mathrm{~b}$ & $0.885 \mathrm{a}$ \\
25 & $32.81 \mathrm{a}$ & $18.96 \mathrm{~b}$ & $22.29 \mathrm{~b}$ & $28.92 \mathrm{~b}$ & $0.868 \mathrm{~b}$ \\
50 & $32.81 \mathrm{a}$ & $19.31 \mathrm{~b}$ & $22.29 \mathrm{~b}$ & $28.96 \mathrm{~b}$ & $0.843 \mathrm{~b}$ \\
$r^{2}$ & 0.504 & 0.594 & 0.549 & 0.524 & 0.259 \\
$P$ & 0.0184 & 0.0013 & 0.003 & 0.0047 & 0.0186 \\
\hline
\end{tabular}

${ }^{\mathrm{z}}$ Sprays were administered twice over an 8-week growth period.

${ }^{\mathrm{y}} \mathrm{L}^{*}(\mathrm{Y})=32.848+12.517^{*} \exp \left[0.5^{*} \operatorname{abs}(\mathrm{x}-7.4) / 1.887\right]^{\wedge} 4.375 ; \mathrm{a}^{*}(\mathrm{Y})=12222.8-17208.8 /[1+810.6(\mathrm{x})]^{\wedge} 1 /$ $\left.34916.8 ; b^{*}(\mathrm{Y})=22.294-3.456[1+0.251(\mathrm{x})]^{\wedge} 1 / 34916.8\right) ; \mathrm{C}^{*}(\mathrm{Y})=29.003-5.521 /[1+1.766(\mathrm{x})]^{\wedge} 1 /$ $0.907 ; \mathrm{H}^{*}(\mathrm{Y})=1 /[1.116+0.0014(\mathrm{x})]$. Data were averaged from three readings from three different taproot replications/treatments. Measured $\left(\mathrm{L}^{*}, \mathrm{a}^{*}\right.$, and $\left.\mathrm{b}^{*}\right)$ and calculated $\left(\mathrm{C}^{*}\right.$ and $\left.\mathrm{H}^{*}\right)$ predicted means are presented. Predicted mean values within a column followed by the same letters are not significantly different based on overlap of the $95 \%$ confidence intervals from their respective regression equations.
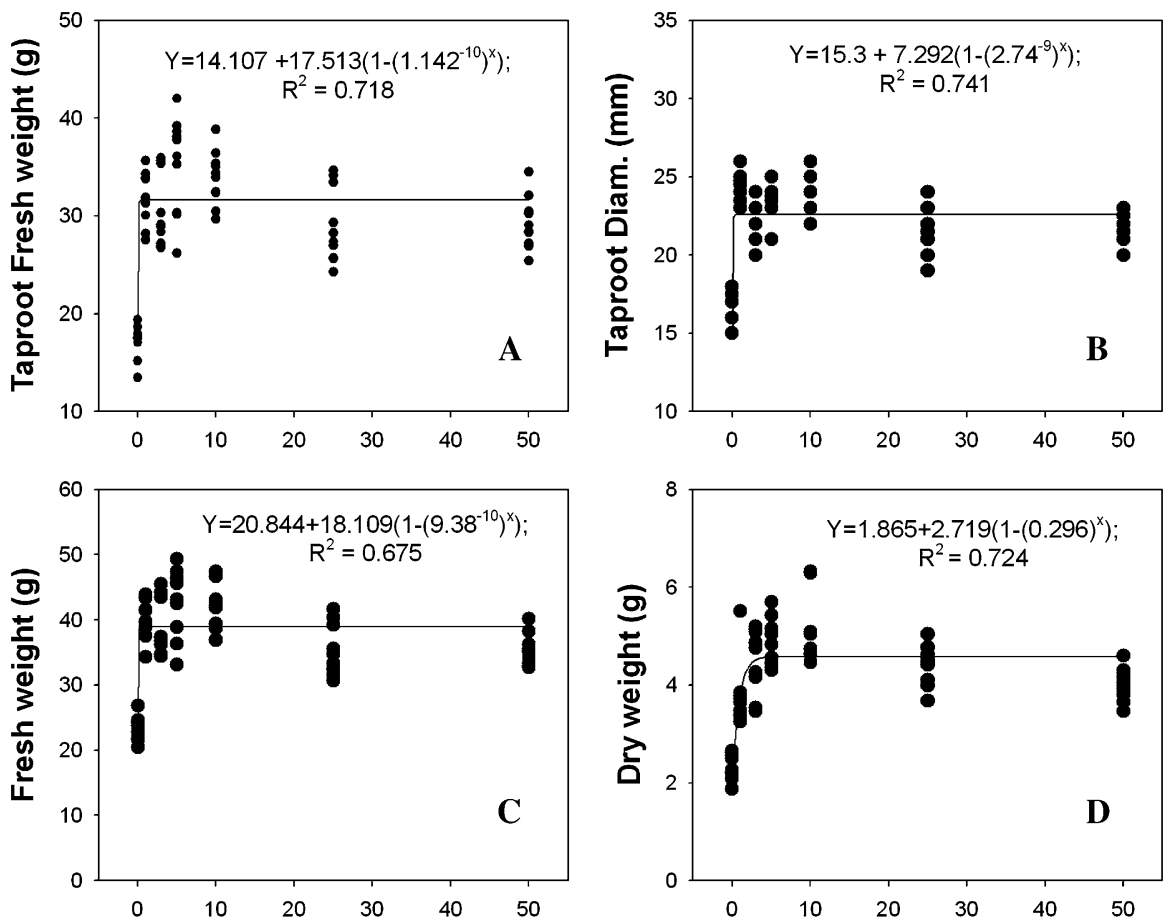

\section{Glycerol Conc. $\left(\mathrm{ml}^{-1} \mathrm{~L}^{-1}\right)$}

Fig. 1. (A-D) Influence of aqueous glycerol spray concentrations applied twice over an 8-week growth period on carrot growth parameters. All correlation coefficients are significant. 
values of the response variables from individual equations were obtained from the REG procedure of SAS (Version 8.2; SAS Institute, Cary, NC).

Measurement of taproot color. The thickest part of the carrot taproot $(\approx 1$ to $2 \mathrm{~cm}$ below the emerging shoot portion) was halved and evaluated for color parameters. Three readings were conducted for each root and averaged. Color was read using the Commission International de l'Eclairage (CIE) Laboratory parameters $\left(\mathrm{L}^{*}, \mathrm{a}^{*}, \mathrm{~b}^{*}\right)$ with a spectrophotocolorimeter LabScan XE Scanner equipped with Universal Software Version 4.0 (Hunter Laboratory, Inc., Reston, VA).

\section{Results and Discussion}

The addition of glycerol to carrot shoots as a spray did not affect their leaf number or shoot height. However, carrot taproots were different as a result of glycerol spray treatments. Taproot diameter for carrot plants sprayed with $5 \mathrm{~mL} \cdot \mathrm{L}^{-1}$ glycerol was $53.8 \%$ greater than untreated controls (Fig. 1B). Shoot fresh weights increased $22.9 \%$ and $9.1 \%$ with 3 and $10 \mathrm{~mL} \cdot \mathrm{L}^{-1}$ glycerol compared with controls, respectively. Taproot fresh weights exhibited a somewhat similar response to glycerol spray treatments (Fig. 1A). The highest taproot fresh weights occurred from plants given 5 and 10 $\mathrm{mL} \cdot \mathrm{L}^{-1}$ glycerol levels and exhibited $150.8 \%$ and $140.3 \%$ increases, respectively, compared with untreated controls. Carrot plants given 25 and $50 \mathrm{~mL} \cdot \mathrm{L}^{-1}$ glycerol sprays had $101.3 \%$ and $82.1 \%$ increases in fresh weight over untreated controls (Fig. 1C-D). The greatest fresh and dry weights were observed in the 5 or $10 \mathrm{~mL} \cdot \mathrm{L}^{-1}$ glycerol treatments. For example, $10 \mathrm{~mL} \cdot \mathrm{L}^{-1}$ glycerol sprays resulted in a significantly higher fresh weight of $41.25 \pm 1.17 \mathrm{~g}$ and a dry weight of $5.38 \pm$ 0.10 g compared with untreated controls, which exhibited a fresh weight of $20.84 \pm$ $0.87 \mathrm{~g}$ and a dry weight of $1.87 \pm 0.08 \mathrm{~g}$. This translated into fresh and dry weight increases of $97.9 \%$ and $173.2 \%$, respectively, compared with untreated controls. Increasing the glycerol concentration above $10 \mathrm{~mL} \cdot \mathrm{L}^{-1}$ did not improve either shoot or root growth. Growth decreased slightly when higher glycerol concentrations were applied. Spraying carrots with glycerol resulted in significantly larger taproots with only a slight increase in shoot mass compared with untreated carrots. The percent shoot:root ratios based on dry

Table 3. Pearson correlation coefficients values for carrot taproot color values and glycerol concentrations.

\begin{tabular}{lccccc}
\hline & Concn & $\mathrm{L}^{*}$ & \multicolumn{1}{c}{$\mathrm{a}^{*}$} & \multicolumn{1}{c}{$\mathrm{b}^{*}$} & $\mathrm{C}^{*}$ \\
\hline Concn & - & -0.219 & $0.661^{*}$ & 0.438 & $0.575^{*}$ \\
$\mathrm{~L}^{*}$ & $-0.219^{\mathrm{z}}$ & - & 0.399 & $0.703^{*}$ & $0.554^{*}$ \\
$\mathrm{a}^{*}$ & $0.661^{*}$ & 0.399 & - & 0.017 & $0.978^{*}$ \\
$\mathrm{~b}^{*}$ & 0.438 & $0.703^{*}$ & 0.017 & - & $0.971^{*}$ \\
$\mathrm{C}^{*}$ & $0.575^{*}$ & $0.554^{*}$ & $0.978^{*}$ & $0.971^{*}$ & - \\
$\mathrm{H}^{*}$ & $-0.718^{*}$ & 0.017 & $-0.876^{*}$ & $-0.582^{*}$ & $-0.757^{*}$ \\
\hline ${ }^{2}$ Values with asterisks were significant at $P \leq 0.05$. \\
Nine color observations were recorded per \\
concentration.
\end{tabular}
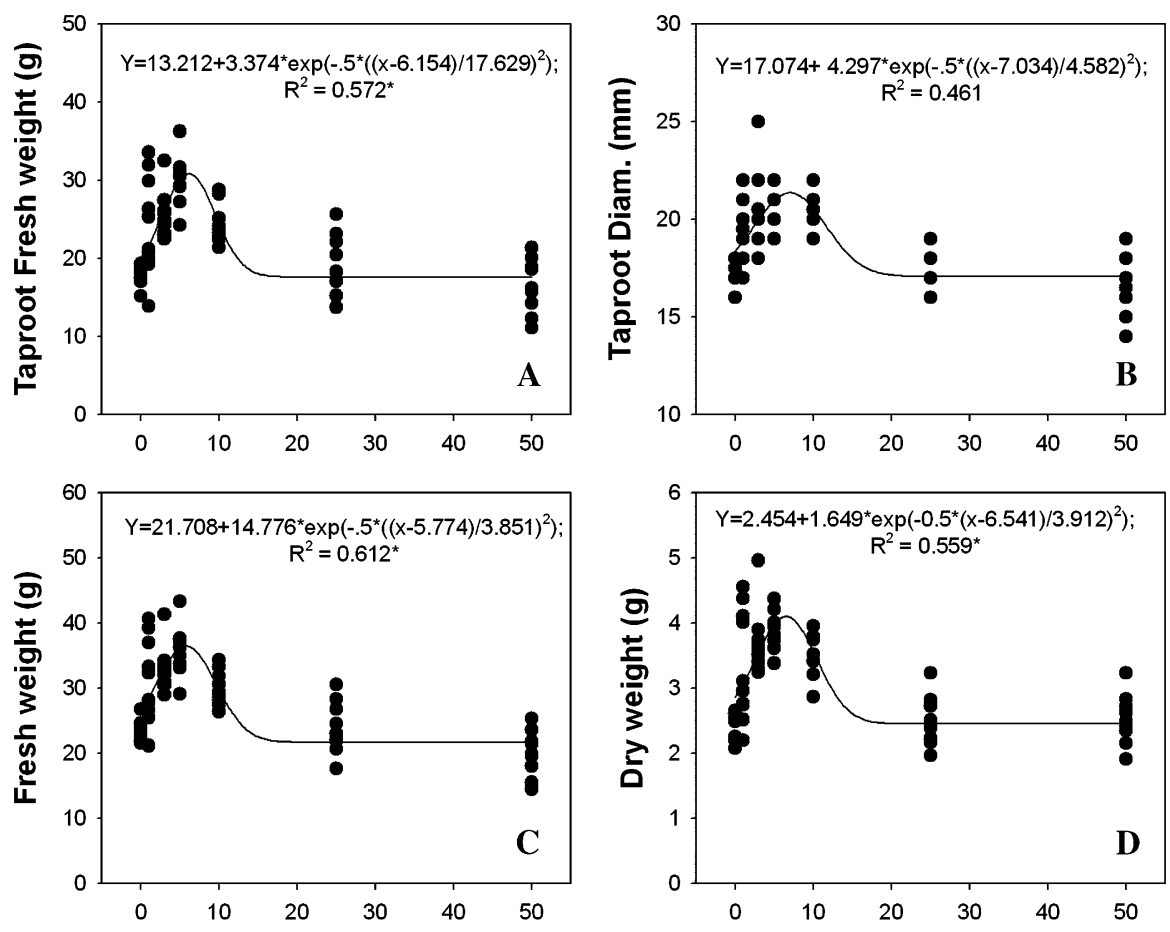

\section{Glycerol Conc. (ml' $\left.\mathrm{L}^{-1}\right)$}

Fig. 2. (A-D) Influence of glycerol drench concentrations applied twice over an 8-week growth period on carrot growth parameters. Correlation coefficient values with asterisks were significant at $P \leq 0.05$.
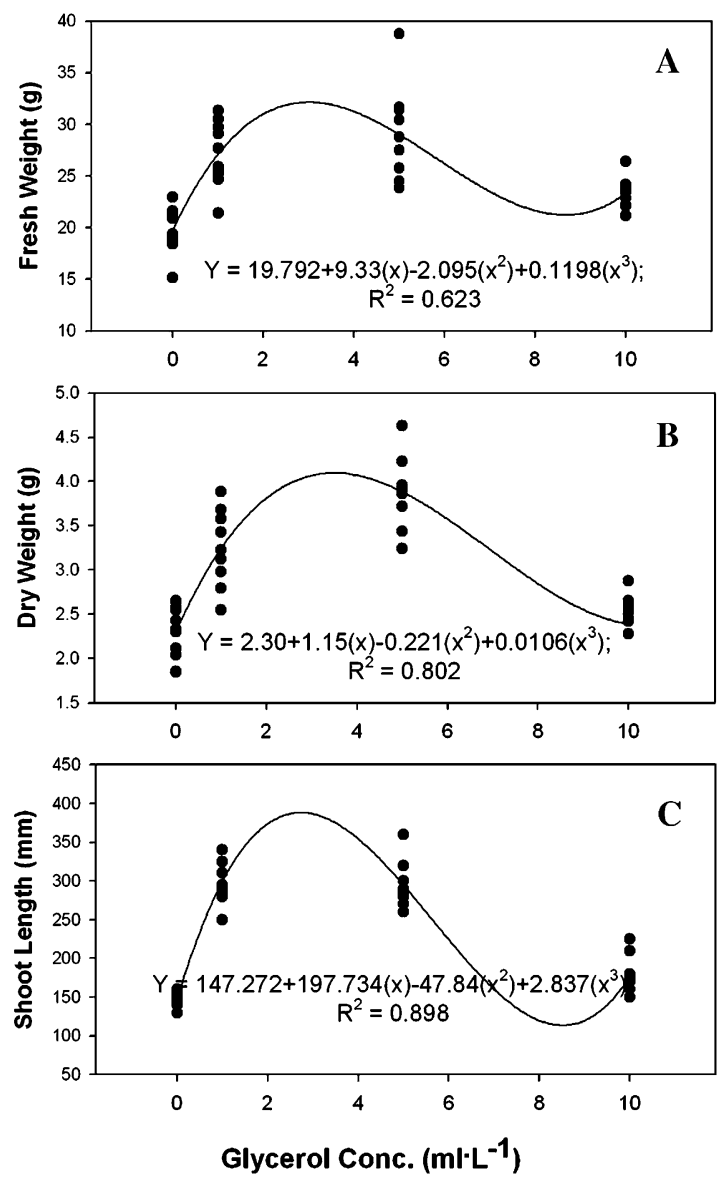

Fig. 3. Influence of aqueous glycerol spray concentrations applied twice over a 4-week growth period on spearmint growth parameters. All correlation coefficients are significant. 
weights were found to be $32.3 \%: 67.7 \%$ for controls, $21.2 \%: 78.8 \%$ for $1 \mathrm{~mL} \cdot \mathrm{L}^{-1}$ glycerol; $17.8 \%: 82.2 \%$ for $10 \mathrm{~mL} \cdot \mathrm{L}^{-1}$ glycerol; and 20.8\%:79.2\% for $25 \mathrm{~mL} \cdot \mathrm{L}^{-1}$ glycerol.

The addition of glycerol as a soil drench did not affect either shoot length or leaf number. Examination of the roots showed significant differences in the taproots for the 3,5 , and $10 \mathrm{~mL} \cdot \mathrm{L}^{-1}$ glycerol treatments compared with untreated controls (Fig. 2A-B). The largest growth responses were obtained from the 1 to $10 \mathrm{~mL} \cdot \mathrm{L}^{-1}$ glycerol treatments; however, 25 and $50 \mathrm{~mL} \cdot \mathrm{L}^{-1}$ glycerol treatments had similar biomass as the untreated controls (Fig. 2C-D). Carrot plants treated with $5 \mathrm{~mL} \cdot \mathrm{L}^{-1}$ glycerol soil drench exhibited significant increases of $22.6 \%, 71.4 \%, 52.5 \%$, and $59.9 \%$ for taproot diameter, taproot fresh weight, plant fresh weight, and plant dry weight, respectively, compared with untreated controls. Growth responses were less in the soil drench treatments compared with the foliar spray treatments. For example, carrots drenched with $5 \mathrm{~mL} \cdot \mathrm{L}^{-1}$ glycerol had $5.74 \pm 0.26 \mathrm{~g}$ shoot weight and $30.19 \pm 0.98 \mathrm{~g}$ root weight, whereas sprayed carrots had $7.47 \pm 1.56 \mathrm{~g}$ shoot weight and $35.37 \pm 1.56 \mathrm{~g}$ root weight. More significantly, carrots drenched with $50 \mathrm{~mL} \cdot \mathrm{L}^{-1}$ glycerol had $3.46 \pm 0.13 \mathrm{~g}$ shoot weight and $16.49 \pm 1.05 \mathrm{~g}$ root weight, whereas sprayed carrots had $6.09 \pm 0.19 \mathrm{~g}$ shoot weight and $29.26 \pm 0.85 \mathrm{~g}$ root weight. Although drenching soil with glycerol could increase carrot growth, the concentration is critical to maximize growth responses (Fig. 2).

Carrot plants that received glycerol sprays were brighter compared with untreated carrots and spectrophotometric analysis of the carrot surfaces confirmed this observation (Table 2). The intensities of redness, "a*," yellowness, "b*," brightness, "L*," and chromaticity, "C*," were greater in carrots with greater growth responses related to glycerol concentrations (Table 2). Significant correlation coefficients were found when comparing glycerol concentrations with $\mathrm{a}^{*}, \mathrm{C}^{*}$, and $\mathrm{H}^{*}$ (Table 3 ). Hue values $\left(\mathrm{H}^{*}\right)$ were lower in glycerol treatments than in controls with carrots sprayed with $5 \mathrm{~mL} \cdot \mathrm{L}^{-1}$ glycerol exhibiting taproots with coloration values of $18.2,22.1,35.7,28.5$, and 0.89 for $\mathrm{a}^{*}, \mathrm{~b}^{*}, \mathrm{~L}^{*}, \mathrm{C}^{*}$, and $\mathrm{H}^{*}$, respectively, whereas untreated carrots manifested color parameters of 14.1, 18.8, 32.8, 23.4, and 0.89 for $a^{*}, b^{*}, L^{*}, C^{*}$, and $H^{*}$, respectively (Table 2 ). There was no difference in spectrophotometric color from taproots drenched with glycerol to those in spray treatments. Like the spray treatments, drenched carrots produced taproots with brighter color values than undrenched carrots. Differences in taproot color between treated and untreated carrots are probably related to the increased growth stimulation causing enhanced maturation of the taproot caused by the glycerol treatments. Color parameters examined through spectrocolorimeters in carrots have been used as a measurement of changes in secondary products, namely carotenoids ( $\alpha$-carotene, $\beta$-carotene, and lutein) (Sun and Temelli, 2001). The "natural" food colorants in carrots consist of provitamin A and carotenoids (Sun and Temelli, 2006). Carrot carotenoids are $\alpha$-carotene ( $10 \%$ to $40 \%$ ), $\beta$-carotene $(60 \%$ to $80 \%)$, lutein ( $1 \%$ to $5 \%)$, and some other minor carotenoids $(0.1 \%$ to $1 \%$ ) (Sun and Temelli, 2006). Glycerol has also been noted to aid the retention of cut flower and plant color (Anonymous, 2011). We noted that glycerol-treated carrots had taproots, whether sprayed or drenched, exhibiting a brighter orange color and retained this color better than untreated controls. It is possible that glycerol might have a role in post-harvest storage of carrots.

Spearmint plants increased growth when treated with foliar spray treatments containing glycerol (Fig. 3). Spearmint cuttings given the $5 \mathrm{~mL} \cdot \mathrm{L}^{-1}$ concentration exhibited $46.6 \%$, $68.7 \%$, and $102.5 \%$ increases in whole plant fresh weight, whole plant dry weight, and shoot length, respectively, compared with untreated controls. Unlike the response in carrots, there was no effect on root biomass increases when compared with shoot biomass because the ratio of root dry weight:shoot dry weight remained constant among the treatments. Shoot fresh weights and root fresh weights in spearmint plants sprayed with $5 \mathrm{~mL} \cdot \mathrm{L}^{-1}$ glycerol increased $45.2 \%$ and $50.5 \%$, respectively, compared with untreated controls. Glycerol sprays stimulated the biomass of the spearmint plant uniformly and did not selectively increase root biomass over shoot biomass yields or vice versa. The $10 \mathrm{~mL} \cdot \mathrm{L}^{-1}$ spray treatments were not as effective in causing growth in- creases as the lower glycerol concentrations (Fig. 3).

Corn plants exhibited enhanced growth responses using 0.1 to $1 \mathrm{~mL} \cdot \mathrm{L}^{-1}$ glycerol foliar spray treatments (Fig. 4). The increasing concentrations of glycerol when tested between 0.1 and $1 \mathrm{~mL} \cdot \mathrm{L}^{-1}$ did not result in a dosagegrowth response relationship (Fig. 4). For example, corn plants treated with $0.5 \mathrm{~mL} \cdot \mathrm{L}^{-1}$ exhibited $83.5 \%, 154.6 \%$, and $90.9 \%$ increases in fresh weight, dry weight, and shoot length, respectively, compared with untreated controls. No root biomass increases occurred with the ratio of root weight:shoot weight remaining constant among all treatments. Glycerol sprays increased the biomass of the corn plant rather selectively promoting shoot biomass over root biomass.

In past studies, glycerol has been used as a penetrating agent in combination with plant regulators and pesticides (Anonymous, 2011; Babiker and Duncan, 1975; Bahadur et al., 2007; Raupach and Kloepper, 1998). Woody or semiwoody plants treated with $0.5 \%$ to $1 \%$ colchicines were mixed with a $10 \%$ glycerol solution to enhance its effect (Anonymous, 2011). In other cases, glycerol is used with copper and zinc salts to aid in the preservation of twigs and buds natural colors and shapes (Anonymous, 2011). In these studies, the direct application of glycerol alone had positive growth promotive effects on three different plant species. The results from these studies
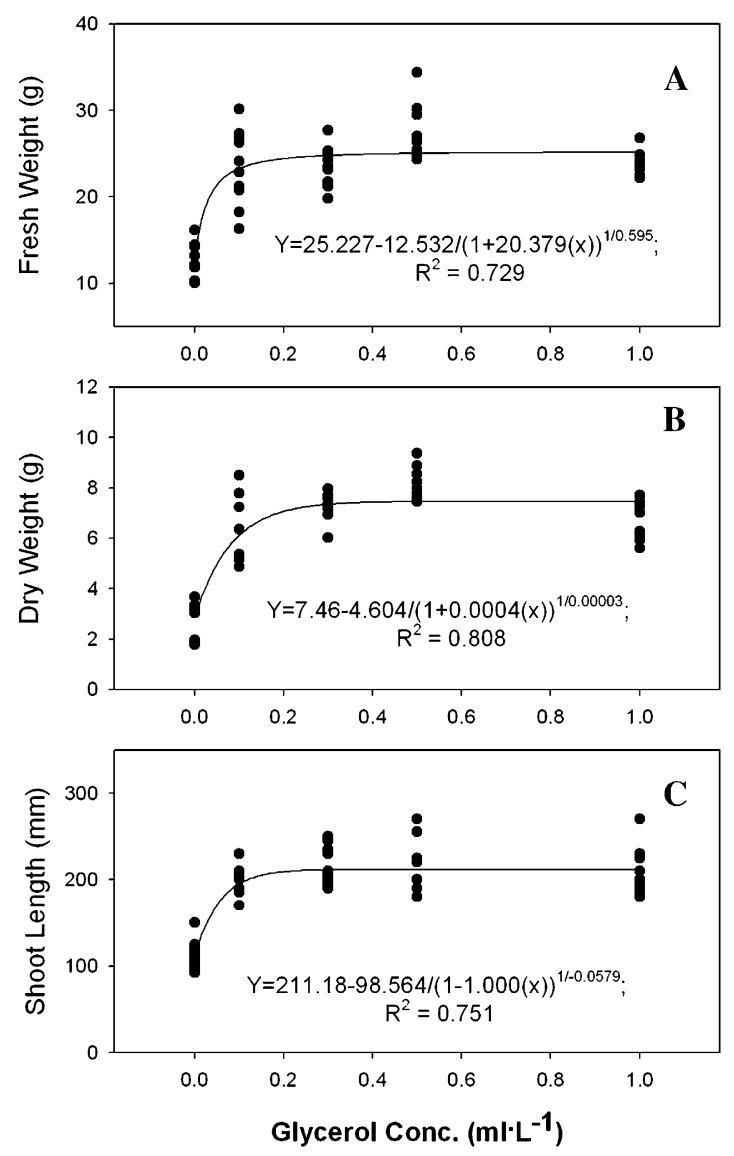

Fig. 4. Influence of glycerol spray concentrations applied twice over a 4-week growth period on corn growth parameters. All correlation coefficients are significant. 
confirm prior observations that glycerol can promote plant growth (Ali et al., 2008; Anonymous, 2011; Bellettre et al., 1999, 2001; Ben-Hayyim and Neumann, 1983). Growth responses with other plant species may be possible. It is not unreasonable to suggest that glycerol may have a market in the agricultural, floriculture, and horticultural fields as a growth-promotive plant product provided its application adheres on the plant. Research should continue that examines the responses of different plants and crops to glycerol and how to most effectively administer this product.

\section{Literature Cited}

Ali, R.M., S.S. Elfeky, and H. Abbas. 2008. Response of salt stressed Ricinus communis L. to exogenous application of glycerol and/or aspartic acid. J. Biol. Sci. 8:171-175.

Anonymous. 2011. Uses of glycerine. The Glycerine Producers' Association, London, UK. 6 Jan. 2011. <http://www.aciscience.org/docs/ Uses of Glycerine.pdf $>$.

Aubert, S., E. Gout, R. Bligny, and R. Douce. 1994. Multiple effects of glycerol on plant cell metabolism. J. Biol. Chem. 269:21420-21427.

Babiker, A.G.T. and H.J. Duncan. 1975. Penetration of bean leaves by asulam as influenced by adjuvants and humidity. Pestic. Sci. 6:655-664.

Bahadur, A., U.P. Singh, B.K. Sarma, D.P. Singh, K.P. Singh, and A. Sigh. 2007. Foliar application of plant growth-promoting rhizobacteria increases antifungal compounds in pea (Pisum sativum) against Erysiphepisi. Mycobiology 35:129-134.

Baweja, P. and D. Sahoo. 2009. Regeneration studies in Grateloupia filicina (J.V. Lamouroux) C. Agardh-An important Carrageenophyte and edible seaweed. Algae 24:163-168.

Bellettre, A., J.-P. Couillerot, A.-S. Blervacq, S. Aubert, E. Gout, J.-L. Hilbert, and J. Vasseur. 2001. Glycerol effects both carbohydrate metabolism and cytoskeletal rearrangements during the induction of somatic embryogenesis in chicory leaf tissues. Plant Physiol. Biochem. 39:503-511.

Bellettre, A., J.P. Couillerot, and J. Vasseur. 1999. Effects of glycerol on growth and somatic embryogenesis in Cichorium leaves. Plant Cell Rpt. 19:26-31.

Ben-Hayyim, G. and Y. Goffer. 1989. Plantlet regeneration from $\mathrm{NaCl}$-selected salt-tolerant callus culture of Shamouti orange (Citrus sinensis L. Osbeck). Plant Cell Rpt. 7:680-683.

Ben-Hayyim, G. and H. Neumann. 1983. Stimulatory effect of glycerol on growth and somatic embryogenesis in Citrus callus cultures. Zeit. Pflanzenphysiol. 1110:331-337.

Demirbas, A. 2009. Progress and recent trends in biodiesel fuels. Energy Convers. Manage. 50: 14-34.

Ebert, J. 2007. Discovering new uses for glycerin. Biodiesel Mag. 4:1-3.

Gautheret, R.J. 1955. The nutrition of plant tissue cultures. Annu. Rev. Plant Physiol. 6:433-484.

Hisajima, S. and T.A. Thorpe. 1985. Carbohydrate utilization and activities of various glycosidases in cultured Japanese Morning-Glory callus. Plant Tiss. Cult. Lett. 2:14-21.

Kaczyna, F. and R. Megnet. 1993. The effects of glycerol and plant growth regulators on Gracilaria verrucosa (Gigartinales, Rhodophyeae). Hydrobiologia 268:57-64.

Kenar, J.A. 2007. Glycerol as a platform chemical: Sweet opportunities on the horizon? Lipid Technol. 19:249-253.

Kim, S.W. and M.J. Oh. 2009. Establishment of plant regeneration and cryopreservation from zygotic embryo-derived embryogenic cell suspensions of Ranunculus kazusensis. Methods Mol. Biol. 547:107-115.

Lawlor, H.J., J.A. McComb, and M.A. Borowitzka. 1989. Tissue culture of Ecklonia radiata (Phaeophyceae, Laminariales): Effects of growth of light, organic carbon source and vitamins. J. Appl. Phycol. 1:105-112.

Lines, S. 2009. An exploding market? Utilizing waste glycerol from the biodiesel production process. Wordpress.com, St. Louis, MO. 1 Dec. 2009. <http://snrecmitigation.wordpress.com/ 2009/04/19/an-exploding-market-utilizing-wasteglycerol-from-the-biodiesel-production-process $>$.

Marián, F.D., P. García-Jiménez, and R.R. Robaina. 2000. Polyamines in marine macroalgae: Levels of putrescine, spermidine and spermine in the thalli and changes in their concentration during glycerol-induced cell growth in vitro. Physiol. Plant. 110:530-534.

McIntyre, C. 2007. Measurement solutions for biodiesel renewable fuels industry, p. 1-28. White Paper, Endress + Hauser Reinach, Switzerland. 1 Oct. 2010. <http://www.de.endress.com/eh/ central/info/resource.nsf/imgref/Download_WP2007-Biodiesel.pdf/\$FILE/WP-2007-Biodiesel. pdf $>$.

Mello, M.O., C.T.S. Dias, A.F.C. Amaral, and M. Melo. 2001. Growth of Bauhinia forficata Link, Curcuma zedoaria Roscoe and Phaseolus vulgaris L. cell suspension cultures with carbon sources. Sci. Agricola 58:1-12.

Pachauri, N. and B. He. 2006. Value-added utilization of crude glycerol from biodiesel production: A survey of current research activities, p. 1-16. In: Proc. ASABE Ann. Intern. Meeting, St. Joseph, MI.

Panis, B. and M. Lambardi. 2005. Status of cryopreservation technologies in plants (Crops and Forest trees), p. 43-54. In: Proc. Int. Workshop "Role of Biotechnology for the Characterisation and Conservation of Crop, Forestry, Animal and Fishery Genetic Resources." FAO, Turin, Italy.

Raupach, G.S. and J.W. Kloepper. 1998. Mixtures of plant growth-promoting rhizobacteria enhance biological control of multiple cucumber pathogens. Phytopathology 88:1158-1164.

Robaina, R.R., G. Garcia-Reina, and A. Luque. 1990. The effects of the physical characteristics of the culture medium on the development of red seaweeds in tissue culture. Hydrobiologia 204/205:137-142.

Silayoi, B. 2001. Cryopreservation of Kluai Namwa (Musa paradisiaca 'Kluai Namwa'). Kasetsart J. 35:225-230

Singh, A., N. Nito, and M. Iwamasa. 1992. Influence of lactose and glycerol on growth and somatic embryogenesis of citrus callus. Acta Hort. 321:606-609.

Sun, M. and F. Temelli. 2001. Supercritical $\mathrm{CO}_{2}$ extraction of carotenoids from carrots and evaluation of products. 5th Internat. Symp. Supercrit. Fluids Sustainable Technologies, Atlanta, GA. 2 Oct. 2010. <http://www.isasf.net/fileadmin/files/ Docs/Versailles/Papers/PN34.pdf>.

Sun, M. and F. Temelli. 2006. Supercritical carbon dioxide extraction of carotenoids from carrot using canola oil as a continuous co-solvent. J. Supercrit. Fluids 37:397-408.

Tomaz, M.L., B.M.J. Mendes, F.D.A.A.M. Filho, C.G.B. Demétrio, N. Jansakul, and A.P.M. Rodriquez. 2001. Somatic embryogenesis in Citrus spp. carbohydrate stimulation and histodifferentiation. In Vitro Cell Biol.-Pl. 37: 446-452.

Towill, L.E. and P. Mazur. 1976. Osmotic shrinkage as a factor in freezing injury in plant tissue cultures. Plant Physiol. 57:290-297.

Vu, J.C.V., R.P. Niedz, and G. Yelenosky. 1993. Glycerol stimulation of chlorophyll synthesis, embryogenesis, and carboxylation and sucrose metabolism enzymes in nucellar callus of 'Hamlin' sweet orange. Plant Cell Tissue Organ Cult. 33:75-80.

Vuke, T.M. and R.L. Mott. 1987. Growth of loblolly pine callus on a variety of carbohydrate sources. Plant Cell Rpt. 6:153-156.

Withers, L.A. and P.J. King. 1979. Proline: A novel cryoprotectant for the freeze preservation of cultured cells of Zea mays L. Plant Physiol. 64:675-678. 